\title{
The professionalization of Brazilian nursing in the written media of the end of the nineteenth century: a gender analysis ${ }^{1}$
}

\author{
Tiago Braga do Espírito Santo ${ }^{2}$ \\ Taka Oguisso ${ }^{3}$ \\ Rosa Maria Godoy Serpa da Fonseca ${ }^{3}$
}

\begin{abstract}
The object is the relationship between the professionalization of Brazilian nursing and women, in the broadcasting of news about the creation of the Professional School of Nurses, in the light of gender. Aims: to discuss the linkage of women to the beginning of the professionalization of Brazilian nursing following the circumstances and evidence of the creation of the Professional School of Nurses analyzed from the perspective of gender. The news articles were analyzed from the viewpoint of Cultural History, founded in the gender concept of Joan Scott and in the History of Women. The creation of the School and the priority given in the media to women consolidate the vocational ideal of the woman for nursing in a profession subjugated to the physician but also representing the conquest of a space in the world of education and work, reconfiguring the social position of nursing and of woman in Brazil.
\end{abstract}

Descriptors: History of Nursing; Gender Identity; Women, Working.

\footnotetext{
${ }^{1}$ Paper extracted from Master's Thesis "As Enfermeiras Francesas na Capital do Brasil (1890-1895)" presented to Escola de Enfermagem, Universidade de São Paulo, SP, Brasil. Supported by Conselho Nacional de Desenvolvimento Científico e Tecnológico (CNPq), process \# 140126/2008-2.

2 RN, Doctoral student in Nursing, Escola de Enfermagem, Universidade de São Paulo. Scholarship holder of Conselho Nacional de Desenvolvimento Científico e Tecnológico (CNPq). E-mail: tbes81@gmail.com.

3 RN, Ph.D. in Nusrsing, Full Professor, Escola de Enfermagem, Universidade de São Paulo, SP, Brazil. E-mail: Taka takaoguisso@uol.com.br, Rosa - rmgsfon@usp.br.
}

Corresponding Author:

Tiago Braga do Espírito Santo

Rua Húngara, 442, Casa 2

Vila Ipojuca

CEP: 05055-010, São Paulo, SP, Brasil

E-mail: tbes81@gmail.com 


\title{
A profissionalização da enfermagem brasileira na mídia escrita no final do século XIX: uma análise de gênero
}

O objeto é a relação entre a profissionalização da enfermagem brasileira e as mulheres, na veiculação de notícias sobre a criação da Escola Profissional de Enfermeiros e Enfermeiras, à luz de gênero. O objetivo desta pesquisa foi discutir a vinculação das mulheres no início da profissionalização da enfermagem brasileira, segundo as circunstâncias e evidências da criação da Escola Profissional de Enfermeiros e Enfermeiras, analisando-se sob a ótica de gênero. As notícias foram analisadas sob o olhar da História Cultural, fundamentada pela concepção de gênero de Joan Scott e da História das Mulheres. A criação da Escola e a prioridade oferecida na mídia, para as mulheres, cristalizam o ideário vocacional da mulher para a enfermagem em uma profissão subjugada ao médico, embora também representasse a conquista de espaço no mundo da educação e do trabalho, reconfigurando a posição social da enfermagem e da mulher, no Brasil.

Descritores: História da Enfermagem; Identidade de Gênero; Trabalho Feminino.

\section{La profesionalización de la enfermería brasileña en los medios de comunicación escritos de final del siglo XIX: un análisis de género}

\begin{abstract}
El objetivo del estudio fue conocer la relación, que existió entre la profesionalización de la enfermería brasileña y las mujeres, en las noticias publicadas sobre la creación de la Escuela Profesional de Enfermeros y Enfermeras, bajo la perspectiva de género. Los objetivos fueron discutir la vinculación de las mujeres en el inicio de la profesionalización de la enfermería brasileña según las circunstancias y evidencias de la creación de la Escuela Profesional de Enfermeros y Enfermeras, analizando bajo la óptica de género. Las noticias fueron analizadas bajo la perspectiva de la Historia Cultural, fundamentada en la concepción de género de Joan Scott y en la Historia de las Mujeres. La creación de la Escuela y la prioridad ofrecida, en los medios de comunicación para las mujeres, cristalizan el ideario vocacional de la mujer para la enfermería en una profesión subyugada al médico, a pesar de que también representaba la conquista de un espacio en el mundo de la educación y del trabajo, reconfigurando la posición social de la enfermería y de la mujer en Brasil.
\end{abstract}

Descriptores: Historia de la Enfermería; Identidad de Género; Trabajo de Mujeres.

\section{Introduction}

The object of this study is the relationship between the onset of the professionalization of Brazilian nursing and women, by broadcasting news about the creation of an educational institution, the Professional School of Nurses (EPEE), the first nursing school in Brazil, in 1890, currently the Alfredo Pinto Nursing School of the Federal University of the State of Rio de Janeiro (EEAP-UNIRIO). The aims are: to discuss the linkage of women to this professionalization by identifying the circumstances and evidence of the creation of EPEE, analyzed under the gender concept of Joan Scott.
Created as an annex to the National Hospice for the Insane (HNA) by Decree 791/1890, the school comprised one of the government initiatives to remedy the human resource crisis triggered by the closure of the Sisters of Charity of St. Vicente de Paulo of the institution where they performed nursing and administration services, since its creation in 1852, when it was called the Pedro II Hospice and was linked to the Santa Casa de Misericórdia(1).

In this text we will understand the profession as a practice that includes all the people possessing 
academic tradition, diploma or equivalent, indicating the occupations that require highly specialized knowledge and skills acquired, at least in part, on a course of a more or less a theoretical nature in an authorized institution. Reaching professional maturity and authority over a field of performance, professional bodies have been developed that have the purposes to safeguard the performance, to determine the rules of admission, training and behavior, and to legally defend the interests of the category(2).

Based on this definition, a structural framework is created for the entire profession, to support it by a triad formed by: educational institutions, organizations of class category and legislation. Therefore, to study the birthplace of nursing in Brazil, through the creation of a school, is to understand the first pillar of the process of professionalization, unveiling determinant transformations of a still obscure period of nursing.

\section{Methods}

This study interprets reality through Cultural History, engaged in the perception of the historical fact by society, thus approaching the interpretation of historically constructed symbols that transmit and perpetuate the social characteristics, thus approaching the anthropological concept of culture that understands history as a constructor of the quotidian ${ }^{(3)}$. Regarding the treatment of the documentation collected, the gender concept of Joan Scott was used, which seeks the meanings of the whys of the events and the bonds existent between the subjects and the social organizations involved. To this end, the author proposes a definition of gender as "a constitutive element of social relationships based on the differences that distinguish the sexes" and also as "a primary form of significant relationships of power". The definition is completed with a breakdown of the first proposition in four aspects that are interrelated in the theater of social relations, namely: the culturally available symbols; the normative concepts expressed in religious, educational, scientific, political and/or legal doctrines; the social organization and the institutions; and the construction of the subjective identities ${ }^{(4)}$.

To base the study on the gender focus, which precedes and crosses all social relations, means to identify the aspects proposed by Scott in the evidence that comprises the historical phenomenon and, by analyzing the material, to understand how social transformation occurred, based mainly on the History of Women that highlights women, even if related to men, families, children, female and male representations, social classes and power, as agents of the historical process $^{(5)}$. The evidence for the study was sought in different documentary sources, despite the difficulty of finding documents referring to the temporal delimitation focus. Among the sources found, of the most interest for the study were the records of articles released by the news media, because it is understood that this, besides being a vehicle of information, is also an instrument of manipulation of interests and of social intervention ${ }^{(6)}$. It is important to emphasize that, the understanding that the document does not take a neutral or objective discourse is intrinsic to this analysis. The production of a discourse is always interlaced with the ideological values of the society that produced it, with it being necessary to seek connections between the content of the source, the forms in which they are expressed and the extra textual conjectures that emerge from the space-time in which they were produced ${ }^{(7)}$. In order to guide the documental search, the temporal delimitation to the year 1890 was appropriate, since it marks the professionalization of Brazilian nursing, being the date of Decree 791 , of $27^{\text {th }}$ September 1890, which established the Professional School of Nurses. The spatial delimitation is the National Hospice for the Insane, where the educational institution was inaugurated as an annex.

Five reports were encountered that cited the creation of the Professional School of Nurses (EPEE). From this universe three were chosen that, due to their relationship with gender issues, were described and analyzed. The archives used were those of the National Library and of the archive of the National Academy of Medicine, both located in the city of Rio de Janeiro, where the news articles of the periodicals "Jornal do Commercio", "O Diário Oficial" and "O Brazil Médico" were searched. In order to make a base for the interpretation of the news records, especially regarding the intentionality of the writing and its target audience, it was necessary to make a biographical abstract of the periodicals, as follows. Founded on $1^{\text {st }}$ October, 1827 and published until the present day (2010), the "Jornal do Commercio" stands out in the Brazilian socio-political scenario as the major newspapers of the capital of the country at the beginning of the Republic. It had as its target audience, important businessmen, politicians and the elite of Rio de Janeiro. Being a prestigious publication, with the offices situated in the Rua do Ouvidor, it is still a reference in the city center of Rio de Janeiro today ${ }^{(8)}$. Published from 1887 to 1956, "O Brazil Médico" was a weekly publication 
of political and professional interests of the Brazilian physician class. The periodical presented the medical scientific production and a column called "Chronicle and News", where news related to the general medical services was published, offering an overview of health at the time ${ }^{(9)}$. Thanks to the transfer of the Portuguese Court to Brazil on $13^{\text {th }}$ May 1808 , the National Press (Diário Oficial) was founded, with a mission to publish and disseminate the official acts of the federal public administration. This source contributed to the research since the publication of news in this period represents the intentionality of dissemination of government procedures, serving as an means of capturing official information that would enable its triangulation with the other news records and evidence ${ }^{(10)}$.

\section{Results and discussion}

We chose to present the results together with the discussion due to the belief that by presenting the identification of each of the sub-items of the concept of gender in the news articles found in parallel with the discussion would facilitate the understanding of the study and be consistent with the method adopted.

\section{The circumstances of the creation of EPEE and women}

The Pedro II Hospice (HPII), named in honor of its main promoter, was inaugurated on $30^{\text {th }}$ November 1852 in Praia da Saudade, currently the Urca neibourhood, in Rio de Janeiro, linked to the Santa Casa de Misericórdia. On that date the Daughters of Charity of St. Vicente de Paulo also came to work in the care and the management of the institution. However, the troubled period of the late nineteenth century brought many socio-political changes, mainly caused by the advance of positivist ideology that, following the proclamation of the Republic in 1889, brought about the separation of the Church and the State, and consequently the secularization of the institutions(11). The prevailing paradigm, which emphasized knowledge and all that could be proven by science, provoked gradual transformations in the society, which obviously reached the HPII. In this institution, a great transformation was caused by Decree No. 142, of $11^{\text {th }}$ January 1890 , that deannexed the Hospício from the Santa Casa de Misericórdia, affirming a republican position. Since homage to the emperor was no longer justified, the name was changed to the National Hospice for the Insane ${ }^{(11)}$.

The nominal change followed several other diverse changes which occurred in a symbolic struggle that, among other things, intended to mark the transition of the governmental regime from monarchical to republican, confirming the representativeness of the policy as a reference of the modernity that installed itself in the country, moving away from the "lethargy of the Monarchy" or the "barbarism of slavery", even though the constructed representations of the African descendants in the Brazilian Republic perpetuated the meanings of their degenerate and criminal nature(12). The HNA was part of this process, symbolizing modernity intended for the nascent Republic, inspired by the most advanced standards and bourgeois values of the civilization, disseminated in the western world and reiterated by the notion of order and progress ${ }^{(9)}$.

The most important Brazilian scientists, doctors and psychiatrists worked in the HNA who, recently returned from studies in Europe, imported to Brazil the French care model, which was based on specialists such as Charcot, Pinel and Esquirol. It therefore became necessary to affirm the position and role of the physician in the hospital. These facts caused increasing clashes with the Sisters of Charity, accustomed to obeying only their hierarchical superior and not a layman, even though a physician $^{(11)}$. The divergence reached its apex with Decree 508 of $21^{\text {st }}$ June 1890 that, when creating the Medical Legal Care for the Insane, appointed Dr. João Carlos Teixeira Brandão, as Director of the HNA. He, affirming his position, allocated lay nurses (not nuns) to take care of patients, in substitution of the Sisters of Charity, in the male Section of the HNA. On $11^{\text {th }}$ August, 1890 the Sisters of Charity left the HNA, the decision having been permeated by conflicts between political and institutional factors, demonstrating the divergence caused by the separation of the Church and State, the resistance of the Sisters of Charity to accept the new proceedures brought by the physicians arrived from Europe and the decisive power relationship between the physicians and the nuns. The physicians, in recognizing the HNA as a field of power and knowledge production, initiated a campaign for the conquest of the institutional administration, with the main articulator being the new director of the hospice, which reduced the power of the Sisters of Charity, removing them from the institutional administration. It is worth noting the similarity of this situation with that which occurred in France in the previous years, where the secularization of its hospitals also took place, in consonance with the new social and political order adopted by the government which differed from that used by hospital institutions of that country ${ }^{(13-14)}$. 
Two measures were taken to solve the human resources problem: the creation of a training school for nurses (EPEE) and the hiring of a quantity of nurses trained in the Salpetriere School, as well as 15 other auxiliary nurses, adding about 40 French professionals. The purpose of this hiring was to immediately substitute the work performed by the nuns. However, it would be naive to think that the choice of nationality and education occurred at random, because the Salpetriere School was strongly influenced by the nursing model of Dr. Bourneville (a prominent French physician, journalist and politician) who inaugurated secular educational institutions and created a reference manual for the training of nurses. Thus, professional advancement was attached to the stabilization of the medical power, which adopted the "Bournevillian" model of nurses as "nuns without habits", possessing the characteristics of devoted caregivers - understood as inherent to women and present in the Sisters of Charity, but also compliant with the tasks determined by the physician ${ }^{(14)}$.

This position can be identified in the circumstances of the creation of the EPEE, the influence of the "normative concepts" determined by Scott. In this case, the normative bias was expressed in the educational doctrines of the French schools of nursing, created and directed by physicians, in addition to its great importance in defining the role of nurses in France. It is noteworthy that these nurses were hired to work in the HNA and that its training school (Salpétrière) determined the patterns of nursing of the time to be adopted in the creation of the EPEE. It is also related to this Bournevillian model, adopted by EPEE in order to train nurses with characteristics of nuns without the habit, which Scott defines as "culturally available symbols", since the object is perceived in order to take advantage of the symbolic and cultural load of the nuns with their aura of abnegation and devotion to the lay women, that unlinked to the Church would be subjugated hierarchically to the physician.

\section{The written media as evidence of the relationship between the creation of the EPEE and women}

The disclosure of the creation of the EPEE in journals of the time can be perceived as a direct consequence of the signing of Decree 791/1890. Of the news articles encountered regarding the institutional inauguration, three stood out as major sources for the study. The first report, published in "Diário Oficial" of $1^{\text {st }}$ October, 1890 was related to the disclosure of a request for collaboration, sent to those responsible for charitable work in Rio de Janeiro that "they support, direct and educate underprivileged girls" to make them "creatures useful to themselves and their homeland", highlighting the need to "broaden the horizon of aspirations" for the girls who "do not find immediate and remunerative application", more than the boys, who received professional education in the institutions (for example the Casa de São José) ${ }^{(15)}$.

The title of the material - Escola de Enfermeiras - School of Nurses (female) - alone modifies the original name of the institution, Escola Profissional de Enfermeiros e Enfermeiras - Professional School of Nurses (male) and Nurses (female), to exclude the male nurses, directing the information only towards women. This fact is reiterated when the text cites the school as an opportunity for girls, describing the EPEE as a "vast field of activity for women, where, due to their delicacy of feelings and purity of caresses there will be no competitors" working as "the complement of the physician". The imperative need to professionalize the "underprivileged" girls is also emphasized, in view of the urgency to train nurses to replace the Sisters of Charity who "abandoned about 500 unfortunate people before the arrival of the nurses of the secular order hired from France"(15). To highlight the underprivileged girls becomes particularly meaningful when related to the context of the implementation of the republican regime that valued the child, interpreting it as an "heir of the Republic", allegorized in the figure of the loving, selfless woman, the bearer of qualities inherent to the action in the private world, consistent with the idea of subordination of the woman to the male figure. Thus, the State started to take responsibility for children, leading them in a political way, reinforcing social categories through the reaffirmation of the female roles ${ }^{(16)}$.

The highlights made in the news article can be interpreted by what Scott calls "subjective identity" that allows the construction of gendered identities to be observed. In this case, the "subjective identities", are constructed by the load of information present in the stereotypes used. This information was socio-historically constructed and transferred to the women, contributing and having contributed to the symbolic and cultural load assigned to the female. Thus, to relate the figure of the woman to that of the Republic, linked to the child, is to use positions stipulated by the socio-historical construction, reinforcing the function of women and of what is expected of them in society. The focus on the broadening of the work horizons for the woman through the opening of a field conducive to the development of 
"delicacy of feelings and purity of caresses", highlights the utility of the function to complement the physician, thereby crystallizing the characteristics understood as inherent to the woman, relating them in a subjugated form to a mostly male professional category. The disclosure of these characteristics allowed the proximity to the category of "culturally available symbols" in which the female sex, covered with sacred value, similar to the representation of the Virgin Mary, the caring mother in all her plenitude, links the image of the nurse to abnegation ${ }^{(17)}$.

The second news article, published in the "Jornal do Commercio", also on $1^{\text {st }}$ October, 1890, under the title "Professional School of Nurses (male and female)" reports on the creation of the training school annexed to the National Hospice for the Insane (HNA) and discloses that, "if such a creation is an advantage to men, it is much more advantageous for women, where the activity widens their horizons and provides them a future in which they may provide important services". Just as in the news article published in the DO, the text relates to the opening of places for men and women, however it highlights the female sex. This news article, as well as perpetuating the polarization between the male and the female, shows that the opening of the school was a possibility of work for the women ${ }^{(18)}$.

The third and final news article analysis, published on $8^{\text {th }}$ October, 1890 in the journal "O Brazil-Médico", begins with glowing reports about the Director of HNA, Dr. Teixeira Brandão, and his initiative of creating the EPEE to train nurses for services in hospitals and hospices of the Republic, highlighting how this initiative was grandiose, both from the practical and moral perspective. From the practical perspective, the text highlights the advantage that medicine would be able to rely on people prepared to deal with patients being then "true assistants of the physician". From the moral perspective, the news article announces the expansion of the horizons of the female activity, still limited at the time, giving them an "honest and highly humanitarian way to acquire the means of subsistence"(19).

The text continues with a description of Decree 791, which created the EPEE, recalling its training role of both men and women, the curricular disciplines and the two year period of the course, the need to perform practice in the wards, the minimum age of 18 years, as well as the strict admission criteria and the need to present certificates of good conduct ${ }^{(19)}$. When relating the "moral side" of the news article (the intention of inserting the woman into the school) with the "practical side" (professionals to help the physician), the intention of training professionals subjugated to the physician category is consolidated. In this regard the observations of Scott are highlighted regarding the "social organizations" that interfere in the delineation of female roles, limiting the possible interpretations of the category of women and defining the female practices through the socio-historically constructed expectations. However, to think of the History of Women is, among other goals, to commit to an analysis that has as a central axis the process of increasing the visibility of women in their struggles and their achievements in the public and private spaces. Thus, the analysis of the creation of the EPEE and the priority given in the media to the female public, by endorsing the field of the History of Women, assumes a dual focus, consisting of natural advances and setbacks for this area of knowledge. On one hand such analysis consolidates the vocational ideal of women for nursing, emphasizing their qualities of a selfless and dedicated carer in a profession subjugated to the physician, on the other, it shows the conquest of space in the world of education and work, contributing to the reconfiguration of the social position and of the woman in Brazil.

Returning to the concept of gender as something socio-political-culturally constructed, resulting in specific products to each historical moment, and highlighting the commitment of science to produce interpretive theories of reality in order to overcome existing knowledge, it is worth pointing out, just as an example of the perpetuation of the gendered social processes that need to be questioned, the parallelism between the above and the conditions of implementation, at the beginning of the 20th century, of other nursing schools in the country, under the same parameters and values, although strongly influenced by English and American nursing, inspired by Florence Nightingale $e^{(20-21)}$.

\section{Conclusion}

Through the contextualized analysis of the evidence encountered, it can be seen that the location and interrelationship of the four constituent elements of the social relationships based on differences that distinguish the sexes, as proposed by Scott, provides a demonstration of the linkage of women to the inauguration of a professional school of nursing. The news articles analyzed are seen as instruments of social intervention reaffirming female roles, taking women from the private and inserting them into the public 
world of education and the labor market conforming to the republican order. Thus, although the image of the woman was being constructed as a product of the male imagery, through the female condition and the difference between the sexes, embodied in the representations that silenced them, the facts analyzed are also facilitators of their visibility and professionalism. This symbolized an evolution in the work of nurses which, from then on, was reconfigured towards training for a distinct for women.

\section{References}

1. Moreira A. Desmistificando a origem da enfermagem brasileira. In: Geovanini T, Moreira A, Scheller SD, Machado WCA. História da enfermagem: versões e interpretações. Rio de Janeiro: Revinter; 2005. p. 59-128.

2. Fundação Getúlio Vargas (BR). Dicionário de ciências sociais. Rio de Janeiro: Fundação Getúlio Vargas; 1987. 2 v.

3. Burke P. O que é história cultural? Rio de Janeiro: Jorge Zahar; 2005. 192 p.

4. Scott J. Gênero: uma categoria útil para os estudos históricos? Educ Realidade. 1990; 16(2):5-22.

5. Pinsky CB. Apresentação. In: Perrot M. Minha historia das mulheres. São Paulo: Contexto; 2007.

6. Luca TR. História dos, nos e por meio dos periódicos. In: Pinsky CB. Fontes históricas. São Paulo: Contexto; 2006. p. $111-55$

7. Guinsburg C. O queijo e os vermes: o cotidiano e as idéias de um moleiro perseguido pela inquisição. São Paulo: Companhia das Letras; 2006. 271 p.

8. Fundação Getúlio Vargas (BR). Dicionário históricobiográfico brasileiro pós 1930. Rio de Janeiro: Ed. FGV; 2001. $5 \mathrm{v}$.

9. Moreira A, Porto F, Oguisso T. Registros noticiosos sobre a Escola Profissional de Enfermeiros e Enfermeiras na revista "O Brazil-Médico", 1890-1922. Rev Esc Enferm USP. 2002;36(4):402-7.

10. Portal da Imprensa Nacional. A Imprensa Nacional [internet]. Brasília (DF) [acesso 2 jun 2009]. Disponível em: http://portal.in.gov.br/in/imprensa1/a-imprensanacional/.

11. Moreira A, Oguisso T. Profissionalização da enfermagem brasileira. Rio de Janeiro: Guanabara Koogan; 2005. 150 p.

12. Schwarcz LM. Virando séculos. 1890-1914: no tempo das certezas. São Paulo: Companhia das Letras; 2000. $184 \mathrm{p}$.
13. Pontes C. Contribuição à história da enfermagem: Escola de Enfermagem Alfredo Pinto: a pioneira das escolas de enfermagem do Brasil. Rev Bras Enferm. $1971 ; 24(3-4): 199-214$

14. Espírito Santo TB. Enfermeiras francesas na capital do Brasil (1890-1895) [dissertação de mestrado]. São Paulo (SP): Escola de Enfermagem da Universidade de São Paulo; 2007. 162 p.

15. Escola de Enfermeiras. Diário Oficial (Rio de Janeiro); 01 out. 1890

16. Gomes VLO. A interpretação do cuidado de Enfermagem à criança em creches, pela ótica de Pierre Bourdieu [tese de doutorado]. Florianópolis (SC): Universidade Federal de Santa Catarina; 2004. 197 p.

17. Perrot M. Minha história das mulheres. São Paulo: Contexto; 2007. 192 p.

18. Escola Profissional de Enfermeiros e Enfermeiras (BR). J Commercio 01 out. 1890; Gazetilha: 1

19. Escola de Enfermeiros (BR). Brazil-Medico. 08 out 1890.

20. Fonseca RMGS. Espaço e gênero na compreensão do processo saúde-doença da mulher brasileira. Rev. LatinoAm. Enfermagem. [periódico na Internet]. jan 1997. [acesso 10 jun 2010]; 5(1):5-13. Disponível em: http:// www.scielo.br/scielo.php?script=sci_arttext\&pid=S0104$11691997000100002 \&$ lng=pt. doi: 10.1590/S010411691997000100002.

21. Fonseca RMGS. Uma leitura generificada da (re) inauguração de um fazer para mulheres: da Inglaterra ao Brasil. Rev Bras Enferm. 2002;55(1):75-84.
Received: June $17^{\text {th }} 2010$ Accepted: Mar. $17^{\text {th }} 2011$ 